\title{
Genetic Transformability of Selected Kenyan Groundnut (Arachis hypogaea L.) Genotypes with IPT Gene Using Cotyledonary Node Explants
}

\author{
Purity G. Limbua $\mathbb{D}^{1,2}$ Mathew P. Ngugi $\mathbb{D}^{1},{ }^{1}$ and Richard O. Oduor $\mathbb{D}^{1}$ \\ ${ }^{1}$ Department of Biochemistry, Microbiology and Biotechnology, Kenyatta University, Nairobi 43844-00100, Kenya \\ ${ }^{2}$ Department of Biological Sciences, Mount Kenya University, Thika 342-01000, Kenya \\ Correspondence should be addressed to Purity G. Limbua; pglimbua@yahoo.com
}

Received 2 May 2021; Revised 16 August 2021; Accepted 5 January 2022; Published 11 February 2022

Academic Editor: Amelia Salimonti

Copyright (C) 2022 Purity G. Limbua et al. This is an open access article distributed under the Creative Commons Attribution License, which permits unrestricted use, distribution, and reproduction in any medium, provided the original work is properly cited.

\begin{abstract}
Groundnut (Arachis hypogaea L.) is an important crop in terms of income and nutrition. Despite its importance, groundnut yield is limited by environmental factors such as drought. This work reports the genetic transformability of Kenyan groundnut (Arachis hypogaea L.) genotypes with isopentenyl transferase (IPT) gene towards drought tolerance. The cotyledonary nodes of six Kenyan adapted groundnuts genotypes (ICGV 12991, CG 7, Red Valencia, ICGV 90704, Chalimbana, and JL 24) were transformed using Agrobacterium tumefaciens strain EHA 101 carrying PNOV-IPT binary vector containing an IPT gene, which was driven by SARK promoter and terminated by TNOS terminator. The vector also contained the phosphomannose isomerase (PMI) gene for the selection of transformed tissues. Putative transformants were tested for the presence of the transgene by PCR designed to amplify the IPT gene sequence. Gene expression was confirmed by RT-PCR. Transformation frequency was calculated as a percentage of the number of putative transformants divided by the total number of infected cotyledonary nodes. This ranged from $9.87 \%$ for ICGV 90704 to $19.77 \%$ for JL 24. Transformation efficiency was calculated as a percentage of the number of PCR positive plants divided by the total number of cotyledonary nodes infected. This ranged from 0\% for ICGV 12991 and Chalimbana to $1.74 \%$ for JL 24. The data suggest the possibility of transforming groundnuts with the IPT gene and regenerating normal transgenic plants. This information will be useful during the transformation of groundnut towards different factors that affect production.
\end{abstract}

\section{Introduction}

Groundnuts (Arachis hypogaea L.) are among the oilseed crops that are cultivated around the world. The production of this crop encounters abiotic stresses such as waterlogging, salinity, and drought, which lead to very low productivity. To solve these challenges, different transformation methods are currently being used to complement the conventional breeding of groundnuts. Some of the successful transformation methods in legumes involve the use of cotyledonary nodes and embryonic axes as explants [1]. These explants have terminal or axillary meristems, which are sources of totipotent cells and hence the best targets for transformation [2].

In this study, six Kenyan adapted groundnut genotypes were taken through Agrobacterium-mediated transformation with IPT gene for drought tolerance. Putative transformants were regenerated using regeneration media supplemented with $20 \mathrm{~g} / \mathrm{L}$ mannose concentration for selection. After the regeneration of putative transformants and successful hardening, the presence of the transgene was confirmed by the use of PCR and RT-PCR molecular techniques.

\section{Materials and Methods}

Six Kenyan adapted groundnut genotypes ICGV 12991, ICGV 90704, Red Valencia, Chalimbana, CG 7, and JL 24 were used for transformation. Sterile groundnut seeds were germinated using Hoagland's media (supplemented with $10 \mathrm{~g} / \mathrm{L}$ Sucrose, $1 \mathrm{mg} / \mathrm{L} \mathrm{TDZ}$, and $8 \mathrm{~g} / \mathrm{L}$ agar) in order to obtain cotyledonary node explants. The cotyledonary 
nodes were obtained by cutting both the epicotyls and hypocotyls approximately $2 \mathrm{~mm}$ above and below the nodal region.

2.1. Gene Construct. The PNOV-IPT binary vector containing an IPT gene driven by SARK promoter and terminated by a TNOS terminator was used for the transformation of groundnuts in this study (Figure 1). The vector also contained the phosphomannose isomerase (PMI) gene as a selectable marker gene. The IPT gene was donated by Dr. Edwardo Blumwald from the University of California, Davis.

The IPT gene catalyzes the rate-limiting step in cytokinin biosynthesis. This gene plays an important role in promoting drought tolerance in transgenic crops by delaying droughtinduced leaf senescence [3]. In order to overcome other challenges associated with leaf senescence, expression of the IPT gene should be during plant maturation, but before the onset of senescence [3]. Therefore, the IPT gene should be driven by the drought inducible SARK promoter so that it can be useful in enhancing tolerance to drought stress by delaying drought-induced leaf senescence in locally adapted groundnut genotypes.

The expression of the $\mathrm{P}_{\mathrm{SARK}}$ :IPT in groundnuts could enable the development of transgenic crops, which can be cultivated in a water-limited environment without significant yield penalties. This created interest to use the P SARK:: IPT construct in this study.

\subsection{Media for Bacterial Culture. Agrobacterium tumefaciens} strain EHA 101 was grown in low salt Luria-Bertani agar (LBA) (Duchefa Biochemie, Netherlands). The media were prepared by weighing thirty grams of LBA agar (containing $5 \mathrm{~g}$ yeast extract, $5 \mathrm{~g}$ sodium chloride $(\mathrm{NaCl}), 10 \mathrm{~g}$ tryptone, and $10 \mathrm{~g}$ agar) and dissolving in one litre of sterile distilled water, and $\mathrm{pH}$ was adjusted to 6.8 . The media were autoclaved at $121^{\circ} \mathrm{C}$ and cooled approximately between 40 and $50^{\circ} \mathrm{C}$, after which $100 \mathrm{mg} / \mathrm{L}$ kanamycin and $100 \mathrm{mg} / \mathrm{L}$ spectinomycin were added. The media were dispensed into Petri plates and allowed to solidify, after which bacterial colonies were inoculated. For liquid media, $20 \mathrm{~g}$ of low salt Luria-Bertani broth (LBB) (containing $10 \mathrm{~g}$ tryptone, $5 \mathrm{~g}$ yeast extract, and $5 \mathrm{~g} \mathrm{NaCl}$ ) was dissolved in one litre of distilled water, and the $\mathrm{pH}$ was adjusted to 6.8. The types and amounts of antibiotics used were similar to those used in the solid media.

\subsection{Culturing Agrobacterium tumefaciens for Infection.} The Agrobacterium tumefaciens strain EHA 101 harbouring the gene of interest was cultured for 3 days and incubated at $26 \pm 2^{\circ} \mathrm{C}$ in the dark. Refreshing of the three-day-old colonies was done by inoculating single colonies in a $50 \mathrm{ml}$ falcon tube containing $20 \mathrm{ml}$ LBB broth supplemented with $100 \mathrm{mg} / \mathrm{L}$ kanamycin and $100 \mathrm{mg} / \mathrm{L}$ spectinomycin. The tubes were fixed horizontally to a bench-top shaker and shaken at $200 \mathrm{rpm}$ overnight at a temperature of $26 \pm 2^{\circ} \mathrm{C}$. Five millilitres of bacterial suspensions was pelleted by centrifugation for 10 minutes at $5000 \mathrm{rpm}$. These cells were then suspended in $20 \mathrm{ml}$ of filter-sterilized infection media. These media were comprised of half-strength Murashige and Skoog (MS) [4] with Gamborg B5 vitamins [5] media supplemented with $100 \mathrm{mM}$ acetosyringone. The tubes were then fixed horizontally on a bench-top shaker and shaken at $200 \mathrm{rpm}$ for 3 hours at $26 \pm 2^{\circ} \mathrm{C}$.

2.4. Infection and Cocultivation of the Explants. For infection of the explants, three millilitres of Agrobacterium suspensions, which had been grown in the infection media, was poured into sterile Petri plates inside a laminar flow hood to avoid contamination. The embryo axes of the cotyledonary node explants were bisected along the longitudinal plane. Several holes were poked on the meristematic regions of the explants with a sterile blade before immersing them in Agrobacterium suspensions for 5 seconds. Excess Agrobacterium was removed from the explants using sterile filter papers. The explants were then cultured into the cocultivation media, comprised of $4.4 \mathrm{~g} / \mathrm{L}$ MS with Gamborg B5 vitamins supplemented with $30 \mathrm{~g} / \mathrm{L}$ Sucrose, $5 \mathrm{mg} / \mathrm{L}$ BAP, $1 \mathrm{mg} / \mathrm{L} \mathrm{TDZ}$, and $8 \mathrm{~g} / \mathrm{L}$ agar. The explants were arranged in such a way that the wounded meristematic nodal region was in direct contact with the media. The explants were then incubated in the dark for three days at a temperature of $27 \pm 1^{\circ} \mathrm{C}$.

2.5. Shoot Induction, Rooting, and Hardening of Putative Transformants. The shoot induction media were comprised of $4.4 \mathrm{~g} / \mathrm{L}$ MS with Gamborg B5 vitamins supplemented with $10 \mathrm{~g} / \mathrm{L}$ Sucrose, $5 \mathrm{mg} / \mathrm{L}$ BAP, $1 \mathrm{mg} / \mathrm{L}$ TDZ, $3 \mathrm{mg} / \mathrm{L}$ Cefotaxime, $8 \mathrm{~g} / \mathrm{L}$ agar, and $20 \mathrm{~g} / \mathrm{L}$ mannose for selecting the transformed plants. The plants which formed shoots of at least $3 \mathrm{~cm}$ in height were transferred into rooting media. The components of the rooting media were $4.4 \mathrm{~g} / \mathrm{L}$ MS with Gamborg B5 vitamins supplemented with $30 \mathrm{~g} / \mathrm{L}$ Sucrose, $1 \mathrm{mg} / \mathrm{L}$ naphthalene acetic acid, $1 \mathrm{mg} / \mathrm{L}$ (NAA), $3 \mathrm{mg} / \mathrm{L}$ Cefotaxime, and $8 \mathrm{~g} / \mathrm{L}$ agar. After the formation of the secondary roots, the putative transformants were carefully removed from the media and washed with running tap water to remove agar, after which they were planted into pots containing autoclaved peat moss (Kekkila Co. Ltd., Tuusula, Finland). These pots were covered with clear polythene bags to prevent excessive evapotranspiration. After three days of transfer, the bags were cut at the corners to allow gradual acclimatization to the environment. The bags were removed seven days. Two days later, the surviving plants were transferred into pots containing garden soil, which was mixed with sand and manure at a ratio of $1: 1: 1$. These plants were kept in the greenhouse, where they grew to maturity.

2.6. Extraction of Plant Genomic DNA and Plasmid DNA. Plant DNA was obtained from $200 \mathrm{mg}$ leaves harvested from 4-week-old putative transgenic plants and wild-type plants following cetyltrimethylammonium bromide (CTAB) method [6]. 


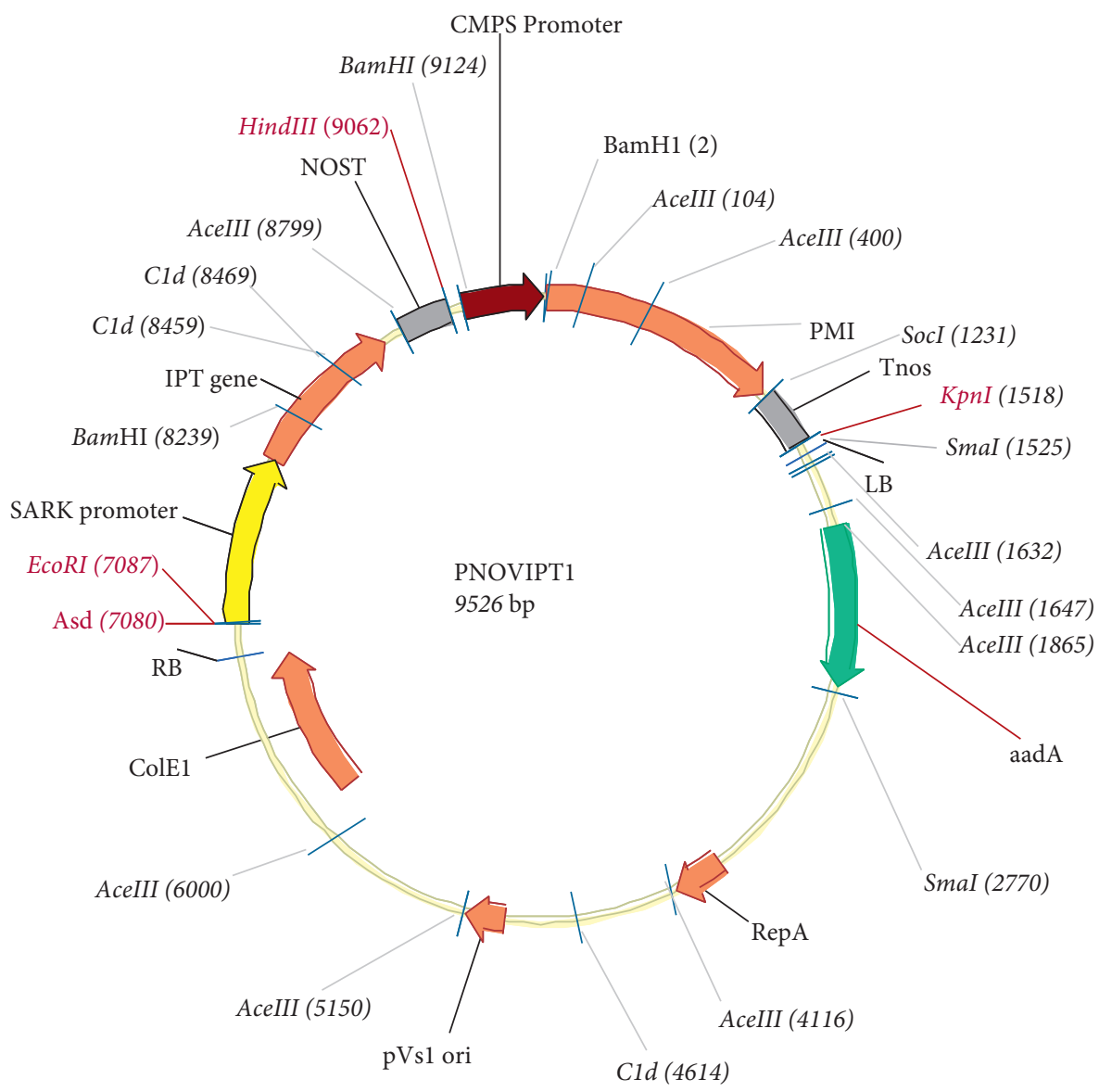

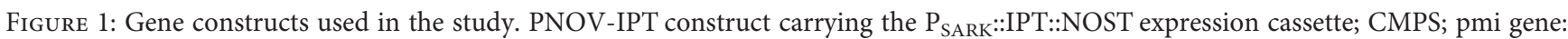
phosphomannose isomerase gene; NOST: nopaline synthase terminator; LB: left border; RB: right border.

For extraction of plasmid DNA, an Agrobacterium tumefaciens strain EHA 101 colony from a fresh culture was inoculated in a $20 \mathrm{ml}$ LB broth medium supplemented with $100 \mathrm{mg} /$ $\mathrm{L}$ kanamycin and $100 \mathrm{mg} / \mathrm{L}$ spectinomycin. The EHA 101 was incubated for 12 hours at $37^{\circ} \mathrm{C}$ with continuous shaking at $3000 \mathrm{rpm}$. The plasmid DNA was extracted using the Qiagen plasmid plus kit following the manufacturer's instructions.

2.7. Polymerase Chain Reaction (PCR) Amplification of the IPT Gene. Forward (5'-ATAGGCGCGCCGAATTCTTCTTCCTTA- $3^{\prime}$ ) and reverse (5'-GCCAAGCTTTCCCGATCTAGTAACATAGAT- $3^{\prime}$ ) primers were used for PCR amplification of the IPT gene. These flanked the SARK promoter and the NOST region targeting the whole expression cassette of $2 \mathrm{~kb}$ size. The PCR programme included initial denaturation for 10 minutes at $98^{\circ} \mathrm{C}$ and then 35 cycles of denaturation at $94^{\circ} \mathrm{C}$ for 30 seconds, annealing at $60^{\circ} \mathrm{C}$ for 30 seconds, extension at $72^{\circ} \mathrm{C}$ for 2 minutes, and final extension of 15 minutes at $72^{\circ} \mathrm{C}$. Each $25 \mu \mathrm{l}$ PCR reaction mixture contained PCR Buffer (1X), dNTPs (0.2 mM), $\mathrm{MgCl}_{2}(1.25 \mathrm{mM})$, forward and reverse primer $(0.4 \mathrm{pmole} / \mu \mathrm{l}$ each), Taq DNA polymerase $(0.1 \mathrm{U} / \mu \mathrm{l})$ (Fermentas Inc., Maryland, USA), and DNA template ( $4 \mathrm{ng} / \mu \mathrm{l})$ added in that order. The final volume was brought to $25 \mu \mathrm{l}$ by adding $18.5 \mu \mathrm{l}$ of nuclease-free sterile water. Two controls, one comprised $24 \mu \mathrm{l}$ of the master mix (premixed ready to use solution containing DNA polymerase, dNTPs, and buffer at optimal concentration) mixed with $1 \mu$ genomic DNA from wild-type groundnut plant (negative control) and the second one comprised $24 \mu \mathrm{l}$ of the master mix mixed with $1 \mu \mathrm{l}$ plasmid DNA isolated from Agrobacterium tumefaciens strain EHA 101 (positive control), were used.

2.8. Agarose Gel Electrophoresis. The 0.5X TBE buffer was poured into a gel electrophoresis tank which was connected to an electric current for 10 minutes at 80 volts so as to prewarm the buffer. The electricity current was switched off before loading the PCR products. Five microlitres of PCR products was mixed with $2 \mu$ l loading dye and $2 \mu \mathrm{l}$ SYBR Green and was loaded into wells in $1 \%$ agarose gel under 0.5 $\mathrm{X}$ TBE buffer. Three microlitres $(3 \mu \mathrm{l})$ of $1 \mathrm{~Kb}$ plus DNA gene ruler (Thermo Scientific USA) was also loaded as a standard into one of the wells. Electrophoresis was carried out at 80 volts for 40 minutes. The gel was viewed using a UV transilluminator, and a photograph was taken.

2.9. Reverse Transcription-Polymerase Chain Reaction (RT-PCR). About $100 \mathrm{mg}$ of young fresh leaf samples was collected from PCR positive plants and one nontransformed 
plant. Total RNA was extracted following Qiagen RNeasy ${ }^{\circledR}$ Plant Mini Kit (Qiagen N. V. Valencia, USA) manufacturer's instruction. The extracted RNA was resuspended in $50 \mu \mathrm{l}$ of RNase-free water. This RNA was treated with 1 unit of deoxyribonuclease I (DNase I) (Invitrogen Corp. Carlsbad, CA, USA) for 15 minutes at room temperature to eliminate any DNA contamination. Complementary DNA was synthesized following the One Taq ${ }^{\circledR}$ One-Step RT-PCR Kit standard protocol (New England Biolabs Inc.). Forward $\left(5^{\prime}\right.$-ATAGGCGCGCCGAATTCTTCTTCCTTA- $\left.{ }^{\prime}\right)$ and reverse (5'-GCCAAGCTTTCCCGATCTAGTAACATAGA T-3') IPT gene-specific primers were used to amplify $2 \mathrm{~kb}$ size expression cassette. The second set of primers used as an internal control was for $25 \mathrm{~S}$ with forward and reverse primers having $5^{\prime}$ ACATTGTCAGGTGGGGAGTT3' and $5^{\prime}$ CCTTTTGTTCCACACGAGATT3', respectively. These primers were expected to amplify 106 base pairs.

The synthesis of complementary DNA and PCR amplification was programmed as follows: one cycle of reverse transcription at $48^{\circ} \mathrm{C}$ for 30 minutes, 1 cycle of initial denaturation for $1 \mathrm{~min}$ at $94^{\circ} \mathrm{C}$, and 40 cycles for 15 seconds of denaturation at $94^{\circ} \mathrm{C}$, followed by 40 cycles for 30 seconds annealing at $65^{\circ} \mathrm{C}$, 40 cycles for $1 \mathrm{~min}$ extension at $68^{\circ} \mathrm{C}$, and 1 cycle for 5 minutes final extension at $68^{\circ} \mathrm{C}$ with a 1 cycle hold at $4^{\circ} \mathrm{C}$.

Five microlitres of PCR products was mixed with $2 \mu \mathrm{l}$ loading dye and $2 \mu \mathrm{l}$ SYBR Green and was loaded into wells in $1 \%$ agarose gel. Three microlitres $(3 \mu \mathrm{l})$ of $1 \mathrm{~kb}$ plus DNA gene ruler (Thermo Scientific USA) was also loaded as a standard into one of the wells. The electrophoresis gel tanks were filled with $0.5 \mathrm{X}$ TBE buffer to submerge the gel. Electrophoresis was carried out at 80 volts for 60 minutes. The gel was viewed using a UV transilluminator.

2.10. Data Management and Statistical Analysis. Data on the number of infected explants, the number of explants forming shoots, the number of plantlets forming roots, the number of plants surviving hardening, and the number of putative transformants were collected and recorded in a Microsoft office excel worksheet before analysis. Survival percentage was calculated as the number of plants which survived hardening divided by the number of plants transferred into hardening and multiplied by 100 . Transformation frequency was calculated as the number of putative transformants divided by the total number of cotyledonary nodes which were infected and multiplied by 100. Transformation efficiency was calculated as the number of PCR positive plants divided by the total number of infected cotyledonary nodes multiplied by 100 . Data were presented in the form of photographs and tables.

\section{Results and Discussion}

After infection, the majority of the explants changed their colour to brown and eventually died at different stages of subculturing in the media containing mannose. In some explants, some cells died while other cells survived the selection (Figure 2). A total of 300 out of 926 infected explants formed shoots with 215 plants attaining the height of approximately $0.6 \mathrm{~cm}$ and were transferred into shoot elongation media.

A total of 168 out of 195 plants transferred to root induction media formed secondary roots and were hardened with a total of 153 out of 168 plants from different genotypes surviving hardening. This reflected a $91.07 \%$ survival percentage. The survival percentage for CG 7, ICGV 12991, ICGV 90704, Chalimbana, Red Valencia, and JL 24 was 96\%, $94.12 \%, 93.75 \%, 90.91 \%, 78.89 \%$, and $91.89 \%$, respectively.

For CG 7 genotype, 24 out of 140 infected explants survived the hardening stage and grew to maturity. In the genotypes ICGV 12991, ICGV 90704, Chalimbana, Red Valencia, and JL 24, 32 plants out of a total of 177 infected plants, 15 plants out of 152 infected plants, 30 plants out of 175 infected plants, 18 plants out of 110 infected plants, and 34 plants out of 172 infected plants, respectively, survived hardening stage and grew to maturity (Table 1).

Genotype JL 24 showed the best response in terms of transformation frequency, followed by ICGV 12991, Chalimbana, CG 7, Red Valencia, and ICGV 90704 in that order (Table 1).

3.1. Detection of Transgene in Putatively Transformed Plants Using PCR. Analysis of putative transgenic plants for $\mathrm{P}_{\text {SARK }}:$ IPT::NOST expression cassette and the pmi marker gene using PCR showed the expected fragment size of $2 \mathrm{~kb}$ (Figure 3) in Red Valencia, CG 7, ICGV 90704, and JL 24 groundnut genotypes. The expected band was not observed in ICGV 12991 and Chalimbana genotypes.

3.2. Detection of Transgene in Putatively Transformed Plants Using RT-PCR. This was done by carrying out an RT-PCR on the PCR positive plants so as to determine the expression of the transgene in the putatively transformed groundnut plants (Figure 4). RT-PCR using $25 \mathrm{~S}$ housekeeping genes as internal control amplified the expected band size of 106 base pairs (Figure 4). RT-PCR amplified a visible band in five out of seven tested PCR positive plants. The other two seldom had any detectable band (Figure 4).

3.3. Transformation Efficiency. Transformation efficiency (TE) ranged from $1.74 \%$ for JL 24 , which gave the highest transformation efficiency, followed by CG 7, Red Valencia, and ICGV 90704 with transformation efficiencies of $1.43 \%$, $0.91 \%$, and $0.66 \%$, respectively. The transformation efficiency of Chalimbana and ICGV 12991 genotypes was 0\% (Table 2).

Three genotypes, CG 7, ICGV 90704, and Red Valencia, had one plant positive for RT-PCR each. JL 24 genotype had two plants positive for RT-PCR (Table 2). There were no PCR or RT-PCR positive plants for ICGV 12991 and Chalimbana genotypes (Table 2).

\section{Discussion}

This study reports the successful transformation and regeneration of four groundnut genotypes. This implies that 


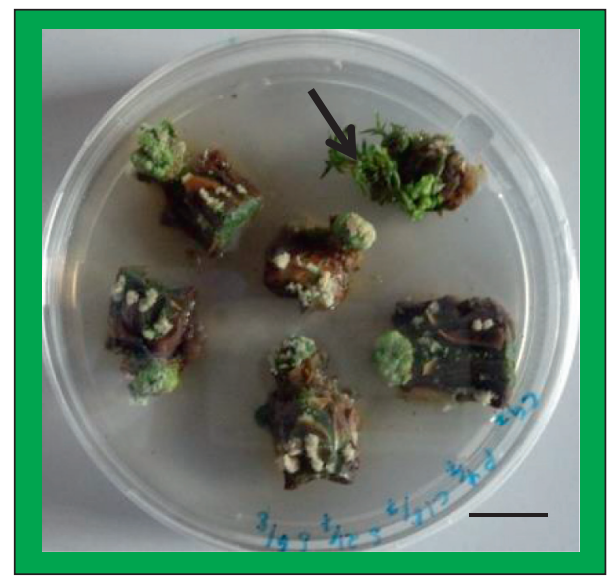

Figure 2: Profile of shooting of Red Valencia explants in selection media. The arrow shows shoots of the surviving explants.

TABle 1: Number of explants in different stages.

\begin{tabular}{|c|c|c|c|c|c|c|c|}
\hline Genotype & $\begin{array}{l}\text { No. of } \\
\text { infected } \\
\text { explants }\end{array}$ & $\begin{array}{l}\text { No. of explants } \\
\text { forming shoots }\end{array}$ & $\begin{array}{l}\text { No. of plants } \\
\text { forming roots }\end{array}$ & $\begin{array}{l}\text { No. of plants } \\
\text { transferred into } \\
\text { hardening }\end{array}$ & $\begin{array}{c}\text { No. of plants } \\
\text { surviving } \\
\text { hardening }\end{array}$ & $\begin{array}{c}\text { Survival } \\
\text { percentage (\%) }\end{array}$ & $\begin{array}{l}\text { Transformation } \\
\text { frequency (\%) }\end{array}$ \\
\hline CG 7 & 140 & 43 & 30 & 25 & 24 & 96 & 17.14 \\
\hline ICGV 12991 & 177 & 52 & 38 & 34 & 32 & 94.12 & 18.08 \\
\hline ICGV 90704 & 152 & 38 & 20 & 16 & 15 & 93.75 & 9.87 \\
\hline Chalimbana & 175 & 56 & 38 & 33 & 30 & 90.91 & 17.14 \\
\hline $\begin{array}{l}\text { Red } \\
\text { Valencia }\end{array}$ & 110 & 52 & 28 & 23 & 18 & 78.26 & 16.36 \\
\hline JL 24 & 172 & 59 & 41 & 37 & 34 & 91.89 & 19.77 \\
\hline Total & 926 & 300 & 195 & 168 & 153 & 91.07 & \\
\hline
\end{tabular}

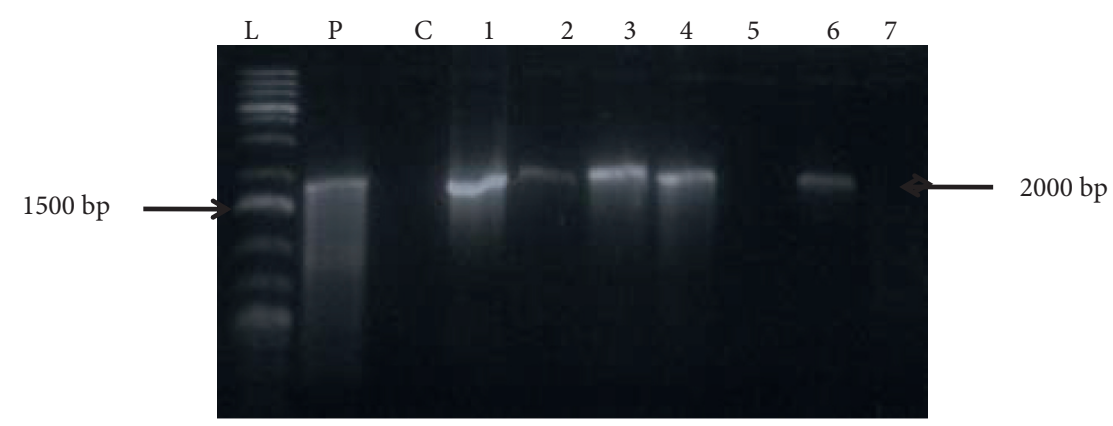

- L: 1 kb plus gene ruler; P: Positive control; C: Negative control; 1: JL 24; 2: ICGV 90704; 3: Red Valencia; 4: CG 7; 5: Chalimbana; 6: JL 24; 7: ICGV 12991

FIGURE 3: PCR analysis of putative T0 groundnut plants using IPT gene-specific primers. L: $1 \mathrm{~kb}$ plus gene ruler; P: positive control; C: negative control; 1: JL 24; 2: ICGV 90704; 3: Red Valencia; 4: CG 7; 5: Chalimbana; 6: JL 24; 7: ICGV 12991.

groundnut cotyledonary nodes are good explants for groundnut transformation and regeneration supporting the work of Verma [7], who reported a successful regeneration of five groundnut genotypes, namely, RG 141, M 13, M 335, PBS 24030, and HNG 10 using cotyledonary node explants.

After infection and cocultivation, the explants changed colour from creamish to brownish. This can be associated with Agrobacterium infection. Many Agrobacterium-mediated transformation-based studies have also reported necrosis and poor survival rate in different plants such as groundnuts [8], finger millet [9], and rice [10]. The browning might be due to a hypersensitive defense reaction in plants, which triggers the bursting of reactive oxygen species after recognition of a specific signal from Agrobacterium infection at the infection site.

During hardening, $91.07 \%$ of putative transgenic plants survived. Therefore, the PSARK::IPT gene construct did not negatively affect the growth of transgenic groundnut plants. 


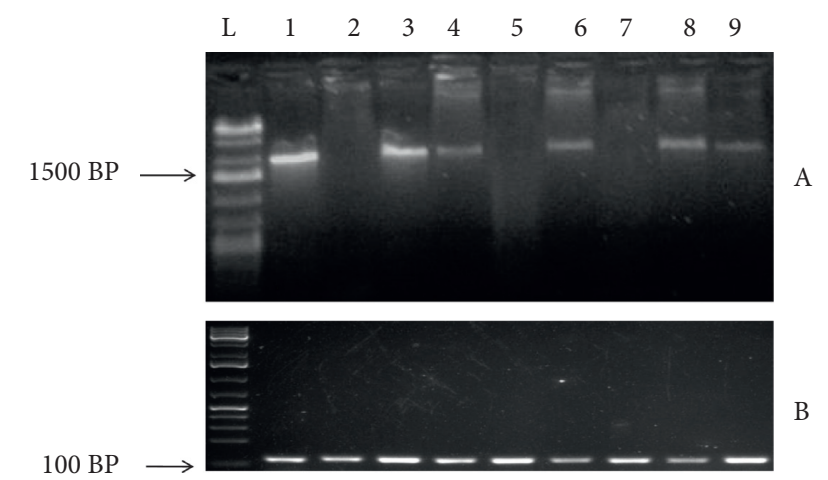

L: $1 \mathrm{~kb}$ plus gene ruler; 1: Positive control; 2: Negative control; 3: cDNA from $J L$ 24; 4: cDNA from JL 24; 5: cDNA from JL 24; 6: cDNA from CG 7; 7: cDNA from CG 7; 8: cDNA from Red Valencia;

9: $c D N A$ from ICGV 90704; A: IPT gene specific primers; B: $25 \mathrm{~S}$ specific primers

FIGURE 4: RT- PCR analysis of PCR positive plants. L $1 \mathrm{~kb}$ plus gene ruler; 1: positive control; 2: negative control; 3: cDNA from JL 24; 4: cDNA from JL 24; 5: cDNA from JL 24; 6: cDNA from CG 7; 7: cDNA from CG 7; 8: cDNA from Red Valencia; 9: cDNA from ICGV 90704; A: IPT gene-specific primers; B: 25S specific primers.

TABle 2: Transformation efficiency.

\begin{tabular}{|c|c|c|c|c|}
\hline Genotypes & Total no. of infected explants & PCR positive & TE (\%) & RT-PCR positive \\
\hline CG 7 & 140 & 2 & 1.43 & 1 \\
\hline CGV 12991 & 177 & 0 & 0 & 0 \\
\hline ICGV 90704 & 152 & 1 & 0.66 & 1 \\
\hline Chalimbana & 175 & 0 & 0 & 0 \\
\hline Red Valencia & 110 & 1 & 0.91 & 1 \\
\hline JL 24 & 172 & 3 & 1.74 & 2 \\
\hline
\end{tabular}

Similar findings were reported by Qin [11], who regenerated positive transformants of New Mexico Valencia A groundnut genotype using the same gene. Besides, a transcription factor DREB1A from Arabidopsis thaliana was introduced to JL 24 groundnut genotype through Agrobacterium-mediated transformation, and there was a regeneration of normal transgenic plants [12].

Genotypes CG 7, ICGV 90704, Red Valencia, and JL 24 were positive for PCR and RT-PCR. This confirms the transformability of groundnut genotypes as reported by Qin [11] using New Mexico Valencia A groundnut genotype. Genotypes ICGV 12991 and Chalimbana did not test positive for PCR. This indicates that transformation frequency depended on the genotype hence supporting the reports by Palmer [13] and Pitzschke and Hirt [14], who stated that Agrobacterium-mediated transformation is genotype-dependent. According to these results, transformation efficiencies ranged between $0 \%$ for Chalimbana and ICGV 12991 and $1.74 \%$ for JL 24 . This supports the $1.8 \%$ transformation efficiency reported after Agrobacterium-mediated transformation of other groundnut genotypes [15].

PCR gel showed samples 1, 3, and 4 from genotypes JL 24, Red Valencia, and CG 7, respectively, having a denser band than samples 2 and 6 from genotypes ICGV 90704 and JL 24, respectively (Figure 2). This can be attributed to the higher concentrations of the starting DNA as the gel photo represented an endpoint PCR.
Genotype CG 7 had 2 plants positive for PCR, while only 1 plant was positive for RT-PCR (Table 2). Similarly, genotype JL 24 had 3 plants positive for PCR, and only 2 were positive for RT-PCR (Table 2). These differences could probably be attributed to the lack of integration of the whole gene cassette during transformation, and therefore, the gene could not be expressed.

Agrobacterium strain EHA 101 used in this study successfully transferred the gene of interest into four groundnut genotypes. This, therefore, indicates that EHA 101 strain is good for groundnut transformation as shown by other works such as McKently [16]. The failure of the two remaining genotypes could be attributed to incompatibility with the Agrobacterium strain EHA 101, as different groundnut genotypes require different strains for effective genetic transformation [17].

\section{Conclusions}

Through Agrobacterium tumefaciens mediated transformation, this study transformed four Kenyan groundnut genotypes with the IPT gene. Two other genotypes were not transformed through the protocol tested. Putative transformants from the six genotypes were analysed for the presence of the transgene by use of PCR and RT-PCR molecular techniques. Only putative transformants from four genotypes, namely, ICGV 90704, CG 7, Red Valencia, and JL 
24, were positive for the transgene as determined by both PCR and RT-PCR. The remaining two genotypes (ICGV 12991 and Chalimbana) were negative for the transgene. This is likely to be due to genotype-dependent factors since transformation has been shown to be genotype-dependent. Transformation frequency ranged from $9.87 \%$ for ICGV 90704 to $19.77 \%$ for JL 24. Transformation efficiency ranged from $0 \%$ for ICGV 12991 and Chalimbana to $1.74 \%$ for JL 24 .

Molecular analysis of putative transgenic plants through PCR and RT-PCR gave positive results for the transfer of the IPT gene into four groundnut genotypes. RT-PCR was positive for five out of seven PCR positive plants. This difference could possibly be due to the rearrangement of the gene in a manner that prevents it from being expressed.

This study describes a protocol for groundnut transformation through direct organogenesis that works across selected Kenyan groundnut genotypes. This protocol will be useful during the transformation of groundnut towards different factors which affect production.

\section{Data Availability}

The data on number of infected explants, number of explants forming shoots, number of plants forming roots, number of plants transferred into hardening, number of plants surviving hardening, survival percentage, transformation frequency, number of PCR positive plants, and number of RT-PCR positive plants used to support the findings of this study are included within the paper.

\section{Conflicts of Interest}

The authors declare that there are no conflicts of interest regarding the publication of this paper.

\section{Acknowledgments}

The authors appreciate Kenyatta University from where this work was done as part of the first authors' Ph.D. studies, and the title of the research thesis was Regeneration and Transformation of Selected Kenyan Groundnut (Arachis hypogaea L.) Genotypes with Isopentenyl Transferase (IPT) Gene towards Drought Tolerance [18]. Kenya Agricultural Livestock and Research Organisation is acknowledged for providing groundnut seeds and Dr. Edwardo Blumwald for providing the gene construct.

\section{References}

[1] A. Chandra and D. Pental, "Regeneration and genetic transformation of grain legumes: an overview," Current Science, vol. 84, pp. 381-387, 2003.

[2] A. T. Swathi, S. K. Jami, R. S. Datla, and P. B. Kirti, "Genetic transformation of groundnut (Arachis hypogaea L.) using cotyledonary node as explant and a promoterless gus::nptII fusion gene based vector," Journal of Biosciences, vol. 31, pp. 235-246, 2006.

[3] R. M. Rivero, M. Kojima, and A. Gepstein, "Delayed leaf senescence induces extreme drought tolerance in a flowering plant," Proceedings of the National Academy of Sciences of the United States of America, vol. 104, no. 49, pp. 19631-19636, 2007.
[4] T. Murashige and F. Skoog, "A revised medium for rapid growth and bio assays with tobacco tissue cultures," Physiologia Plantarum, vol. 15, no. 3, pp. 473-497, 1962.

[5] O. L. Gamborg, R. A. Miller, and K. Ojima, "Nutrient requirements of suspension cultures of soybean root cells," Experimental Cell Research, vol. 50, no. 1, pp. 151-158, 1968.

[6] G. C. Allen, M. A. Flores-Vergara, S. Krasynanski, S. Kumar, and W. F. Thompson, "A modified protocol for rapid DNA isolation from plant tissues using cetyltrimethylammonium bromide," Nature Protocols, vol. 1, no. 5, pp. 2320-2325, 2006.

[7] A. Verma, C. P. Malik, V. K. Gupta, and Y. K. Sinsinwar, "Response of groundnut genotypes to plant growth regulator (BAP) to induce direct organogenesis," World Journal of Agriculture Sciences, vol. 5, no. 3, pp. 313-317, 2009.

[8] Q. S. Zheng, B. Ju, L. K. Liang, and X. H. Xiao, "Effects of antioxidants on the plant regeneration and GUS expressive frequency of peanut (Arachis hypogaea) explants by Agrobacterium tumefaciens," Plant Cell, Tissue and Organ Culture, vol. 81, pp. 83-89, 2005.

[9] S. Antony Ceasar and S. Ignacimuthu, "Agrobacterium-mediated transformation of finger millet (Eleusine coracana (L.) Gaertn.) using shoot apex explants," Plant Cell Reports, vol. 30, no. 9, pp. 1759-1770, 2011.

[10] A. Karthikeyan, S. K. Pandian, and M. Ramesh, "Agrobacterium-mediated transformation of leaf base derived callus tissues of popular indica rice (Oryza sativa L. sub sp. indica cv. ADT 43)," Plant Science, vol. 181, no. 3, pp. 258-268, 2011.

[11] H. Qin, Q. Gu, J. Zhang et al., "Regulated expression of an isopentenyltransferase gene (IPT) in peanut significantly improves drought tolerance and increases yield under field conditions," Plant and Cell Physiology, vol. 52, no. 11, pp. 1904-1914, 2011.

[12] P. Bhatnagar-Mathur, M. J. Devi, D. S. Reddy et al., "Stressinducible expression of at DREB1A in transgenic peanut (Arachis hypogaea L.) increases transpiration efficiency under water-limiting conditions," Plant Cell Reports, vol. 26, no. 12, pp. 2071-2082, 2007.

[13] A. G. Palmer, R. Gao, J. Maresh, W. K. Erbil, and D. G. Lynn, "Chemical biology of multi-host/pathogen interactions: chemical perception and metabolic complementation," Annual Review of Phytopathology, vol. 42, no. 1, pp. 439-464, 2004.

[14] A. Pitzschke and H. Hirt, "New insights into an old story: Agrobacterium-induced tumour formation in plants by plant transformation," The EMBO Journal, vol. 29, no. 6, pp. 1021-1032, 2010.

[15] C. M. Higgins and R. G. Dietzgen, "Genetic transformation, regeneration and analysis of transgenic Peanut," Australian Centre for International Agriculture Research, vol. 48, no. 86, 2000.

[16] A. H. McKently, G. A. Moore, H. Doostdar, and R. P. Niedz, "Agrobacterium-mediated transformation of peanut (Arachis hypogaea L.) embryo axes and the development of transgenic plants," Plant Cell Reports, vol. 14, no. 11, pp. 699-703, 1995.

[17] G. Krishna, K. B. Singh, E. Kim, V. K. Morya, and W. P. Ramteke, "Progress in genetic engineering of peanut (Arachis hypogaea L.) a review," Plant Biotechology Journal, vol. 13, pp. 147-162, 2005.

[18] P. G. Limbua, M. P. Ngugi, and R. O. Oduor, Regeneration and Transformation of Selected Kenyan Groundnut (Arachis hypogaea L.) Genotypes with Isopentenyl Transferase (IPT) Gene towards Drought Tolerance, Ph.D thesis, Kenyatta University, Nairobi, Kenya, 2018. 